\title{
Job Satisfaction of the Highly Educated: The Role of Gender, Academic Tenure, and Comparison Income
}

\author{
Keith A. Bender* \\ John S. Heywood** \\ Department of Economics and Graduate Program in Human Resources \\ and Labor Relations, University of Wisconsin-Milwaukee
}

\begin{abstract}
The determinants of job satisfaction are estimated for Ph.D. level scientists in the United States across academic and nonacademic sectors. Female scientists report lower job satisfaction than males in academia but higher job satisfaction than males in the nonacademic sector. Academic scientists with tenure have substantially greater job satisfaction than non-academic scientists but academic scientists without tenure report similar levels of satisfaction as non-academic scientists. Finally, in each sector, job satisfaction is greater when comparison income is greater in their own sector, while comparisons across sectors generally do not affect job satisfaction.
\end{abstract}

JEL: J28, J44

Key Words: Job satisfaction, highly educated workers, gender differences

* Corresponding author; Department of Economics, PO Box 413, University of Wisconsin-Milwaukee, Milwaukee, WI 53201, phone: 414-229-4761, fax: 414-229-3860, email: kabender@uwm.edu.

** Department of Economics, PO Box 413, University of Wisconsin-Milwaukee, Milwaukee, WI 53201, phone: 414-229-4310, fax: 414-229-3860, email: heywood@uwm.edu.

Acknowledgements: The authors thank the National Science Foundation and William Rayburn for securing access to the restricted data and to Dan Hamermesh, Kostas Mavromaras and the participants at seminars at the University of Aberdeen, Scotland and the University of Wisconsin-Milwaukee. The use of US National Science Foundation (NSF) data does not imply NSF endorsement of the research methods or conclusions contained in this report. 


\section{Job Satisfaction of the Highly Educated: The Role of Gender, Academic Tenure, and Comparison Income}

\section{INTRODUCTION}

Economists have been slow to examine job satisfaction. Despite early examinations by Freeman (1978) and Hamermesh (1977), Bartel (1981) identified only a small handful of studies by economists at the start of the 1980s but more than 3500 by other social scientists. In the last decade this balance has changed as economists have produced numerous articles and monographs examining the determinants of job satisfaction and the consequences of job satisfaction on labor market outcomes. The current catalog of determinants include that the youngest and oldest workers have greater job satisfaction (Clark, Oswald and Warr, 1996), that women have greater job satisfaction in the US and UK (Clark, 1997; Sousa-Poza and Sousa-Poza, 2000), that union members have less job satisfaction (Clark, 1996; Bender and Sloane, 1998; Heywood, Siebert and Wei, 2002), that those with higher comparison earnings report lower job satisfaction (Clark and Oswald, 1996) and that expectations get built into job satisfaction relatively quickly (Hamermesh, 2000).

Among the more intriguing findings has been that additional education results in lower job satisfaction. This results despite the recognized association of education with higher earnings and job attributes generally recognized as more desirable. The usual explanation relies on expectations (Clark and Oswald, 1996). The more educated have higher expectations for the pecuniary and non-pecuniary returns from their jobs, and so are more easily disappointed and dissatisfied. Yet, the persistence of these expectations is perplexing given Hamermesh (2000), and more study of the highly educated is warranted.

In this study we examine the determinants of job satisfaction for the most highly educated, those who have completed a Ph.D. in the sciences. Despite this seemingly narrow focus, several advantages are associated with such an examination. First, this group of workers has often been identified as key for innovation and creating technological progress. This identification has resulted in estimating the determinants of productivity for scientists (Levin and Stephan, 1991), the adequacy of their supply (Stephan and Levin, 1991) and the rewards to their education (Stephan and Everhart, 1998). ${ }^{1}$ Second, the inclusion of a single education variable in typical estimates of job satisfaction may be misleading as the general findings need not apply to the most highly educated. Third, the homogeneity of the sample allows us to control for variables excluded from typical estimates. Thus, our entire

\footnotetext{
${ }^{1}$ For a review of economic studies of the sciences and of the labor market for scientists see Stephan (1996).
} 
sample would be identified as professionals with a Ph.D. degree in typical surveys, but we are able to identify much finer gradations within these categories, which could well generate excluded variable bias in typical estimates.

More generally, the motivation for studying the job satisfaction of highly educated scientists is, in part, the perception that higher satisfaction should be associated with greater productivity. Thus, if the determinants of job satisfaction are understood, researchers may be able to contribute to creating conditions and compensation packages that enhance productivity. Indeed, managers concerned with maximizing the impact of their research and development staff are interested in exactly this connection (Kim and Oh, 2002). The research presented here provides a first step toward making such a contribution.

Specifically, we focus on three areas of the job satisfaction of the highly educated. First, we explore differences in job satisfaction by gender. Second, we investigate the role of tenure, unique to academic jobs, on job satisfaction. Third, we compare job satisfaction of academics to that of nonacademics by examining the role of comparison income on job satisfaction across the two sectors.

In what follows Section 2 describes the literature of job satisfaction for the highly educated to date and sets the stage for our contribution. Section 3 describes our data and presents descriptive statistics. Section 4 presents our basic estimation with a focus on the relative satisfaction of academics among the highly educated, particularly the role of gender, tenure status, and comparison income. Section 5 concludes and suggests avenues for future research.

\section{Job SATISFACTION AND EDUCATION}

General studies typically show that the more educated have lower job satisfaction (Clark and Oswald, 1996). ${ }^{2}$ Yet, there have been a few studies by economists focusing exclusively on the highly educated, and these studies are often limited to academics. ${ }^{3}$ Thus, Ward and Sloane (2000) draw on detailed data from Scottish academics confirming that comparison earnings help determine job satisfaction but finding that non-pecuniary benefits such as relations with colleagues, the nature of teaching and publication success are more important determinants. They find that

\footnotetext{
${ }^{2}$ The failure of education to bring happiness is not a phenomenon limited to the workplace. Hartog and Oosterbeek (1998) demonstrate that overall life satisfaction is lower for the highly educated compared to those with an intermediate level of education.

${ }^{3}$ Recent studies, e.g. Ehrenberg (2003), Zoghi (2003) and Robst, VanGilder and Polacheck (2003), of the academic labor market have also examined the determinants of earnings, the extent of discrimination, the public-private earnings gap and earnings differences in the field.
} 
those academics in science are the least satisfied all else equal, and interestingly, they find that women are no less satisfied than men. They attribute the absence of the typical gender difference to the homogeneity of the sample. In a sample of the highly educated they suggest female workers should have the same expectations as their male counterparts and so the same job satisfaction. This explanation was reiterated in Sloane and Ward (2001) using the same sample of academics to show that women over the age of 35 have significantly higher job satisfaction. The difference between cohorts is seen as a function of reduced representation of women among the older group creating lower job expectations. Also investigating differences by gender, Hagedorn (1996) presents evidence that the job satisfaction of female academics is lower when their earnings fall below the earnings of comparable males.

Oshagbemi (2000) demonstrates that among university instructors in the UK employment tenure in higher education does not correlate with job satisfaction but that longer tenure at their current university positively correlates with job satisfaction. This confirms more general findings that those with high job satisfaction are less likely to move (Akerlof, Rose and Yellen, 1988). Ormsby and Ormsby (1988) examine the influence of unionization on the job satisfaction of faculty. Examining data before and after campuses become unionized they find that satisfaction with pay increased following unionization but no other indicators of satisfaction were influenced. Pfeffer and Langton (1993) confirm theoretical work by Lazear (1989) arguing that pay compression can promote cooperation and harmonious relations in the workplace. Their empirical estimates show that faculty report greater job satisfaction and are more likely to work collaboratively the lower the wage dispersion.

Economists have also studied the job satisfaction of the highly educated in the health professions. Shields and Ward (2001) examine the job satisfaction of nurses in the National Health Service (NHS) finding that the lack of promotion and training opportunities have a stronger impact on job satisfaction than do workload or pay. Confirming studies mentioned earlier they also find that those who report being dissatisfied are much more likely to quit the NHS. In the United States, Bashaw (1998) studies the job satisfaction of employed physicians confirming the role of comparison earnings, finding that female physicians have greater satisfaction, in contrast with the Scottish academics, and that those in general practice and pediatrics have the greatest job satisfaction. The last finding is telling as it suggests that the more educated even among the highly educated sample of physicians are the least satisfied all else equal. This follows as the residencies and length of specialty training for surgeons, anesthesiologists and others exceed that of those in general practice and pediatrics. A similar finding by Bashaw shows that those who are board certified typically have lower job satisfaction even controlling for specialty, earnings 
and the usual controls. Certification indicates mastery of a specialty but is not required to practice in that specialty. It is, in short, an educational credential. Like the more general measure of years of education it is valued in the market place but appears to be associated with lower job satisfaction.

We contribute to these findings by examining the determinants of job satisfaction for a wide cross-section of scientists in the United States all of whom have earned a Ph.D. degree. We start by noting that unlike those that examine only a single profession, physicians, nurses or academics, we will be able to compare across workplace settings and occupations while holding the level of education constant.

\section{DATA AND VARIABLeS}

We draw data from the 1997 Survey of Doctorate Recipients (SDR) conducted by the U.S. National Opinion Research Center for the National Science Foundation, a branch of the United States federal government. The SDR is a nationally representative sample of all Ph.D. graduates in the hard and social sciences prior to 1997 living in the US. Collected in response to the National Research Council's demand for data that allows the integration of occupational detail and academic training, the SDR is conducted every other year asking a set of base questions to which questions unique to that year are added. The 1997 SDR is the most recent wave asking questions about overall job satisfaction. We selected all currently employed scientists for which full information was available yielding a sample of $31,845 .^{4}$

The critical question on job satisfaction asks "How would you rate your overall satisfaction with your principal job during the week of April $15^{\text {th }}$ ?" The choices are "very dissatisfied," "somewhat dissatisfied," "somewhat satisfied," and "very satisfied." These responses are ordered from values of 1 to 4 in increasing satisfaction.

Table 1 presents the average job satisfaction, the percent reporting being very satisfied and the average salary for the overall sample and for broad groups of scientists including economists. These statistics are further broken out by the two employment sectors. ${ }^{5}$ As is apparent, most scientists report reasonably high levels of job

\footnotetext{
${ }^{4}$ Much of the data from the SDR are publicly available, including information on job satisfaction. However, we also employ data that are restricted from public use. These variables include annual earnings, detailed job codes (to determine the disciplines), race/ethnicity, age, marital status, health limitations, and tenure status. See the SDR website at 'http://sestat.nsf.gov/' for more details on both versions of the SDR data.

${ }^{5}$ The SDR does allow for a further distinction between government and 'business' employment for nonacademic scientists. However, the sample sizes for the government sector for some disciplines are very small. Therefore, to
} 
satisfaction with slightly more than half reporting being very satisfied and the average response being about 3.4. These figures do not vary greatly across academic disciplines ${ }^{6}$ or sectors. Overall, the academics are more satisfied than nonacademics (3.43 compared to 3.37). Across disciplines, the highest value is 3.56 for academics working in management science and the lowest is 3.23 for academics working in nonscience (“Other”) disciplines.

There is substantial dispersion in salaries. Overall, academics have an average salary of $\$ 59,881$, while nonacademics earn $\$ 80,070$ on average. Across disciplines this ranges from a lows of almost $\$ 54,000$ for academic social scientists to highs of over $\$ 100,000$ for management scientists and health scientists in the nonacademic sector.

As the satisfaction variable reflects an ordered response, we follow the tradition in economics of estimating the determinants by assuming an underlying continuous latent variable measuring job satisfaction. This latent variable is assumed to fit a cumulative normal and the resulting estimation is an ordered probit (McKelvey and Zavonia, 1975) in which cut-points are simultaneously estimated to identify the four responses.

The survey provides also details a series of other important, but standard, control variables, which we call the 'Basic Variables'. These include the respondents' gender, race, age, marital status and health limitations. Also included are the hours worked, whether the current job is temporary, whether the current job is full time and whether the respondent is job sharing. The survey provides a set of indicator variables for fringe benefits including pensions, vacation leave and profit sharing. There are also indicators of three intervals of establishment size.

Another set of variables, titled 'SDR Variables' are unique to the SDR dataset. First, there are indicators of the respondents' primary activity or responsibility: teaching, management, computing, research or other. In addition, for academics a variety of indicators detail tenure status (nonacademics are considered 'tenure not applicable’). Finally, a series of variables identify whether or not the respondents' current work is related to their Ph.D. degree, and whether a respondent is currently working on a 'postdoc'. Descriptive statistics for all of these variables are presented in Table 2.

Several differences across the academic and nonacademic sectors are apparent. First, the share of workers who are female is higher in academia and lowest in the business sector. Academics and government workers are more likely to have pensions available, while business scientists are more likely to have profit sharing. As might be

have a more comparable sample, we often include only the results for the 'business' sector below. In general, separate results by government or business sector are similar.

${ }^{6}$ A list of the academic subdisciplines which comprise these more aggregated disciplines are given in Appendix Table 2. 
expected, those in the nonacademic sector (particularly business) are the more likely to work in small establishments. Approximately half of academics have tenure on their job, ${ }^{7}$ while over 80 percent of academics say that their job closely relates to their decree, compared to just over half of nonacademics. Finally, there are three times as many postdocs in the academic sector (7.9 percent) compared to the nonacademic sector (2.3 percent).

\section{Determinants of Job Satisfaction}

Initially, we estimate a simple ordered probit regression of the determinants of job satisfaction, following the lead of the previous economics literature on job satisfaction. The results for the entire sample are given in the first column of Table 3. Women have no higher job satisfaction in this sample, although blacks, Asians and those of "other races" all report lower job satisfaction than whites. The result for blacks contradicts the positive coefficient found in representative samples (Bartel, 1981) but confirms the negative coefficient found among another highly educated group, US physicians (Bashaw, 1998). The married report greater job satisfaction and those with health difficulties report lower job satisfaction. Age shows the typical U-shape found in studies using representative samples (Clark, Oswald and Warr, 1996).

Those with higher earnings report greater job satisfaction, but those reporting more hours of work have the same satisfaction as those reporting fewer hours of work. Pensions and profit-sharing plans are positively associated with job satisfaction. Workplace size is associated with lower job satisfaction mirroring results from representative samples (Idson, 1990). Among the disciplines, those in math and engineering report lower job satisfaction while those in management and health sciences report greater job satisfaction relative to economists.

As indicated, academics and government workers have no greater job satisfaction than private sector workers, ceteris paribus, but those scientists without tenure have significantly lower job satisfaction. Those scientists who identify their primary functions as managing or computing have lower job satisfaction than those doing research. Those doing teaching report insignificantly different job satisfaction from those doing research.

Finally, we present evidence on the role of education mismatches. Those scientists who claim their current job closely relates to their degree report substantially greater satisfaction. As will be seen, this persists regardless of the sector in which the scientist works. Moreover, those who report their job relates to their degree report indicate

\footnotetext{
${ }^{7}$ Tenure is typically awarded to faculty after a period of 6 to 8 years on an "up or out" basis. The awarding of tenure provides a very high degree of job security such that typically only malfeasance can be grounds for dismissal.
} 
an intermediate degree of satisfaction. They report more job satisfaction than those whose job does not at all relate to their degree but less satisfaction than those whose degree closely relates. ${ }^{8}$

The regression estimation in column 1 of Table 3 is reproduced for each of the subsamples in columns 2 through 4 . The estimation for academics generally mirrors that for the entire sample. One exception is that female academics in the US report significantly lower job satisfaction contrasting with female academics in Scotland (Ward and Sloane, 2000) who report similar satisfaction and with females in more general samples in the US and UK who typically report greater satisfaction. Other unique aspects for academics are the higher job satisfaction reported for those with vacation leave and the lower satisfaction associated with currently being employed as a postdoc.

The estimation for government workers also closely follows the overall estimation but there are a few differences. First neither women nor racial minorities report different levels of job satisfaction. Similarly, no discipline is associated with job satisfaction significantly different from that of economists. Unlike the general estimation or any of the other subsamples, those in government report greater job satisfaction with increased hours. This seems anomalous and may reflect that those working more hours in the government are more nearly on an upward moving career path which generates greater job satisfaction.

The estimation for scientists working in business is perhaps the most interesting. The first unique result is that those who are doing teaching within their business report significantly greater job satisfaction. The second unique result is that women in private business report significantly greater job satisfaction. Thus, the overall finding of no female result reflects offsetting influences among academics and those in business. Women have greater job satisfaction than men in private business and lower job satisfaction than men in academia. Finally, as in the government, there is no difference in job satisfaction across disciplines (relative to economists) but like academics, blacks and Asians report lower job satisfaction.

Hidden behind these estimates is the issue of sample selection. The choice of sector may influence job satisfaction and may be associated with unmeasured variables. In turn, these variables may be correlated with the included regressors, thereby biasing their coefficients. In an effort to examines this concern, we estimated sectoral

\footnotetext{
${ }^{8}$ These results contrast with Allen and van der Velden (2001) who show that measures of "over-education” and "under-education" in the general population do not influence job satisfaction, although earlier evidence by Tsang and Levin (1985) did find a negative relationship between over education and job satisfaction. Belfield and Harris (2002) use a sample of UK university graduates finding mixed support for the notion that better job matches result in higher job satisfaction.
} 
choice models together with the job satisfaction equations. ${ }^{9}$ While the results indicate that sample selection is an issue for the business sector, neither the pattern of results for that sector or either of the others were altered by the estimation. Given that the results were not substantially changed, we proceed by reporting only the non-selection corrected results below.

\section{Gender and Job Satisfaction}

In this section we examine further the contrasting results on the gender variable across sectors. The negative relationship between job satisfaction and academic women are similar to results in Sloane and Ward (2001) who also find a negative relationship, although only for women who are younger than 35 years old. ${ }^{10}$ Conversely, here women in the business sector have higher job satisfaction, and in this respect they match the representative samples and cast doubt on the hypothesis from others that no gender difference should be expected among the highly educated. It appears that among the highly educated, the important determinant of gender differences is the sector in which they work. ${ }^{11}$

Further disaggregating the role of gender on job satisfaction leads to some interesting differences by discipline. Table 4 reports the results. ${ }^{12}$ Although in the overall sample there is no evidence of significant differences by gender for all disciplines combined, some individual disciplines do show differences. Female economists, hard scientists and engineers have significantly lower job satisfaction, while women who are trained in the sciences but are in nonscience disciplines have significantly higher job satisfaction. Further disaggregating by sector shows that in addition to academicians in the above disciplines, female social and managerial scientists who

\footnotetext{
${ }^{9}$ This was accomplished using the Limdep v8.0 routine that corrects for sample selection in an ordered probit estimation. Besides the job satisfaction variable specification utilized in Table 3, a sectoral equation also needed to be specified. This sectoral choice equation included all the variables from Table 3 as well as a set of variables assumed to influence sectoral choice but not job satisfaction. These variables included: mother and father's education level, geographic region of bachelor degree institution, geographic region of Ph.D. granting institution, whether the respondent is a 'new' Ph.D. of six or fewer years, and the Carnegie class of their Ph.D. granting institution. The results of these estimations are available from the authors.

${ }^{10}$ Sloane and Ward (2001) find positive female effect among an older cohort. We split our sample at several ages, including that of 35 used by Sloane and Ward but found no significant differences by age. In particular, the negative female effect among academics and the positive female effect among those in business persisted both above and below cuts in age anywhere between ages 30 and 45 .

${ }^{11}$ We recognize that this difference might reflect a sorting of workers with different levels of job satisfaction across sectors.

${ }^{12}$ The government sector is not included in this table since in no estimation was the female coefficient significant.
} 
are in academia also have lower job satisfaction than their male counterparts. Female engineers in the business sector also experience lower job satisfaction. Only women in nonscience occupations working in the business sector follow the pattern from representative samples by expressing higher job satisfaction than males.

Although the results in Table 4 control for differences in female and male characteristics, they do not allow for differences in the returns to those characteristics across gender. Therefore, Table 5 reports results from ordered probit regressions estimated separately for each gender in both the academic and business sectors. Examining the results for the academic sector, we find differences in the significance of variables across genders. For example among academics, race plays a stronger role among males than among females, the negative relationship between age and job satisfaction is less for females, and except for difficulty in seeing, there is less influence of disabilities on job satisfaction for females. In addition, the positive effect of increased salary emerges as less important for female academics, while having a temporary job influences the job satisfaction of females. Other differences include a greater role for the discipline indicators but less of a role for the tenure status of women compared to men.

The final two columns in Table 5 report the variable coefficients across gender for those in the business sector. Black females have lower job satisfaction while black males experience no difference in their job satisfaction, ceteris paribus. The difference in the effect of salary is smaller than in the academic sample, and there is now a significantly positive effect of being in a postdoc for females compared to males.

\section{Academic Tenure and Job Satisfaction}

The finding from the overall equation that academics report no different job satisfaction deserves further inquiry. One might suspect that having held earnings constant in the estimation, the increased freedom and flexibility of academics would have resulted in significantly greater job satisfaction. Table 6 follows the evolution of the coefficient on academics in the overall equation as the list of controls is expanded. The initial estimation includes all of the demographic variables, the discipline indicators, health status, the fringe benefit indicators, earnings and hours (identified as 'Basic variables' in Table 2). The coefficient on the academic indicator is almost four times its size in Table 3 with a double-digit t-statistic. The size of the coefficient and its t-statistic drop modestly when the primary responsibility ('Activity') indicators are included. It drops again when the indicators of how closely the current work fits with the degree ('Relate’) are included. At this point everything except the tenure indicators are 
included and academics still report significantly greater satisfaction. Adding those indicators recovers the insignificant coefficient from Table 3 as the t-statistic drops from 6.487 to 0.986 .

Thus, controlling for tenure status plays a critical role in determining the relative job satisfaction of academics. To further explore this two additional estimations were estimated from slightly different samples. The first sample consists of all nonacademic scientists plus those academic scientists who have tenure. The estimation from the first column of Table 3 is replicated (obviously without the controls for tenure) and the coefficient for academics is shown in the first row of the second panel in Table 6. As is evident, those academics having tenure report significantly higher job satisfaction than those outside academia. Despite the full set of controls, the t-statistic remains above eight. The second sample consists of all nonacademic scientists plus those academic scientists who are not tenured. Again, the estimation from the first column of Table 3 is replicated and the coefficient for academics is shown in the second row of the second panel in Table $6 .{ }^{13}$ The coefficient for academics is now smaller than in the original estimate and even further from statistical significance. Thus, those academics without tenure report similar job satisfaction as those outside academia but those with tenure report substantially greater job satisfaction. ${ }^{14}$

\section{Comparison Income and Job Satisfaction}

We now examine the role of comparison income in the job satisfaction of each of our major sectors. We estimate the same three job satisfaction equations as done in Table 3 for academics and business but add a measure of comparison income. Comparison income for an individual is typically estimated from a comprehensive earnings equation based on the characteristics of the worker and the job (Clark and Oswald, 1996). This estimated comparison income measure acts as a proxy for a market wage for the individual accounting for qualifications, characteristics and the nature of the job. When the individual earns more than the comparison income, greater job satisfaction is typically reported and vice versa. Thus, a dummy variable is constructed equal to one when actual exceeds comparison income. This is included as a determinant of job satisfaction.

\footnotetext{
${ }^{13}$ The estimation includes all of the tenure related indicators except that for achieving tenure.

${ }^{14}$ Naturally, the casual relationship may not run only from tenure to job satisfaction. While tenure implies job security which workers value, those academics who are more successful and have higher job satisfaction are surely more likely to be awarded tenure.
} 
While the typical approach has been to include a single comparison earnings measure, our interest in the two sectors in which scientists work suggests an alternative specification. Thus, we use estimated earnings equations for each sector and generate two separate measures of comparison income. Therefore, every individual in the sample will have their own earnings measured relative to comparison income in their own sector and relative to comparison income in the alternative sector. Table 7 summarizes the results. ${ }^{15}$

Overall, the results show that relative income is important. Both of the relative income indicators show that job satisfaction is increased when income is greater than predicted income in either sector. However, disaggregating by sector indicates a similar story. Academics report greater satisfaction when their own earnings are above the comparison earnings of academics and nonacademics. Similarly, the satisfaction of scientists in business is sensitive to their own comparison income as well as comparisons with academic salaries, although this effect is statistically significant only at the ten percent level.

We next examine the importance of comparison income within each discipline to see if this pattern is repeated across disciplines. The estimates, also reported in Table 7, show many positive and significant relationships isolating the importance of comparison income. Yet, there are differences. Academic social scientists follow a different pattern from above, with increasing satisfaction when income is greater than academic comparison income, but no effect with nonacademic comparison income. 'Business' social scientists similarly report higher satisfaction when income is compared to other business social scientists but not academics. This pattern is repeated for 'hard' scientists. The job satisfaction of business engineers are influenced by both comparison measures, while others such as mathematicians and health scientists are not influenced by either. Further results show that only one sector's comparison income is an important correlate with job satisfaction. Relative academic pay for economists and 'other' occupations are important, while relative nonacademic pay for management scientists are influential on job satisfaction. Clearly, sector and discipline specific effects are critical in determining the role of comparison income among the highly educated. ${ }^{16}$ General patterns of comparison income in aggregate samples represent only an average of the differing and off-setting patterns of less aggregate samples.

\footnotetext{
${ }^{15}$ Regressions were also estimated for workers in government, although the coefficients on the comparison income dummy variables were rarely significant and so are not reported here. The full results from the estimates are available in a data appendix from the authors.

${ }^{16}$ The results presented previously on the gender and academic tenure differences in job satisfaction are not significantly changed when we add in the controls for comparison income.
} 


\section{CONCLusions}

By focusing on the job satisfaction of the highly educated, this paper has presented a series of findings that amplify, and modify, those that precede it. First, several traditional results from representative samples have been confirmed among the highly educated. These include the role of earnings, the role of marital status, health limitations and many of the fringe benefits. Second, we present a new and more complex pattern for gender. Among those scientists working in business we confirm the traditional pattern of the more satisfied female workers. Yet, among those scientists working in academia we find just the opposite: females are less satisfied. Third, we emphasize the large increase in job satisfaction associated with being a tenured academic. This increase is relative both to nonacademics and to those academics that do not have tenure. Note, however, this is not an increment in satisfaction associated with academia per se as academia yields an insignificant difference in job satisfaction when it is not associated with tenure. Fourth, strong confirmation of the role of comparison earnings is found. This includes comparison not only within a worker's sector but also across to other sectors. This role does, however, vary considerably across discipline and sector.

This initial investigation of the job satisfaction of the highly educated points to other areas of research. First, a more thorough investigation of the gender difference in job satisfaction is warranted to examine the causes of such a difference. Indeed, one would think that with the flexibility of academic jobs, women, who may be more likely to demand flexible jobs if they are primary caregivers to other household members, would be more satisfied than men. A second issue involves the apparent job mismatch for a substantial portion of the sample. Many scientists report either performing tasks that are not closely related to their education or are working in a nonscience occupation. Since these have implications for job satisfaction, further investigation of why these scientists are not doing what they were trained to do would be an interesting avenue of further research. 


\section{REFERENCES}

Akerlof, G. A., Rose, A. K. and Yellen, J. L. (1988). Job switching and job satisfaction in the US labor market. Brookings Papers on Economic Activity, 2, pp. 495 - 582.

Allen, J. and van der Velden, R. (2001). Educational mismatches versus skill mismatches: Effects on wages, job satisfaction and on-the-job search. Oxford Economic Papers, 53, pp. 434 - 542.

Bartel, A. P. (1981). Race differences in job satisfaction: A reappraisal. Journal of Human Resources, 16, pp. 295 303.

Bashaw, D. (1998). Gender, Earnings and Job Satisfaction: The Case of US Physicians, Ph.D. Dissertation, Department of Economics, University of Wisconsin-Milwaukee, UMI number 9916558.

Belfield, C. and Harris, D. (2002). How well do theories of job matching explain variations in job satisfaction across education levels? Evidence for UK. Applied Economics, 34, pp. 535 - 48.

Bender, K. A. and Sloane, P. J. (1998). Job satisfaction, trade unions and exit-voice revisited. Industrial and Labor Relations Review, 51, pp. $222-40$.

Clark, A. E. (1997). Job satisfaction and gender: Why are women so happy at work? Labour Economics, 4, pp. 341 $-72$.

Clark, A. E. (1996). Job satisfaction in Britain. British Journal of Industrial Relations, 34, pp. 189 - 217.

Clark, A. E. and Oswald, A. J. (1996). Satisfaction and comparison income. Journal of Public Economics, 61, pp. $359-81$.

Clark, A. E., Oswald, A. J. and Warr, P. (1996). Is job satisfaction U-shaped in age? Journal of Occupational Psychology, 69, pp. $57-81$.

Ehrenberg, R. G. (2003). Studying ourselves: The academic labor market. Journal of Labor Economics, 21, pp. 267 $-87$.

Freeman, R. B. (1978). Job satisfaction as an economic variable. American Economic Review, 68, pp. 135 - 41.

Hagedorn, L. S. (1996). Wage equity and female job satisfaction: The role of wage differentials in a job satisfaction causal model. Research in Higher Education, 37, pp. 569 - 99.

Hamermesh, D. S. (2000). The changing distribution of job satisfaction. Journal of Human Resources, 36, pp. 1-30.

Hamermesh, D. S. (1977). Economic aspects of job satisfaction. In: O. Ashenfelter and W. Oates (eds.), Essays in Labor Market Analysis, John Wiley, New York, pp. 53 - 72. 
Hartog, J. and Oosterbeek, H. (1998). Health, wealth and happiness: Why pursue a higher education? Economics of Education Review, 17, pp. 245 - 56.

Heywood, J. S., Siebert, W. S. and Wei, X. (2002). Job satisfaction and worker sorting: The case of union and government jobs. Industrial and Labor Relations Review, 55, pp. 595 - 609.

Idson, T. L. (1990). Establishment size, job satisfaction and the structure of work. Applied Economics, 11, pp. 606 28.

Kim, B. and Oh, H. (2002). Economic compensation compositions preferred by R\&D personnel of different R\&D types and intrinsic values. $R \& D$ Management, 32, pp. $47-59$.

Lazear, E. P. (1989). Pay equity and industrial politics. Journal of Political Economy, 97, pp. 561 - 80.

Levin, S. and Stephan, P. (1991). Research productivity over the life cycle: Evidence for academic scientists. American Economic Review, 81, pp. 114 - 32.

McKelvey, R. and Zavonia, W. (1975). A statistical model for the analysis of ordinal level dependent variables. Journal of Mathematical Sociology, 4, pp. 103 - 20.

Ormsby, J. and Ormsby, S. (1988). The effect of unionization on faculty job satisfaction: A longitudinal study. Journal of Collective Negotiations in the Public Sector, 17, pp. 153 - 60.

Oshagbemi, T. (2000). Is length of service related to the level of job satisfaction? International Journal of Social Economics, 27, pp. $213-26$.

Pfeffer, J. and Langton, N. (1993). The effect of wage dispersion on satisfaction, productivity and working collaboratively. Administrative Science Quarterly, 38, pp. 382 - 407.

Robst, J., VanGilder, J. and Polachek, S. (2003). Perceptions of female faculty treatment in higher education: which institutions treat women more fairly? Economics of Education Review, 22, pp. 59-67.

Shields, M. and Ward, M. E. (2001). Improving nurse retention in the National Health Service in England: The impact of job satisfaction on intentions to quit. Journal of Health Economics, 20, pp. 677 - 701.

Sloane, P. J. and Ward, M. E. (2001). Cohort effects and job satisfaction of academics. Applied Economics Letters, 8, pp. $787-91$.

Stephan, P. (1996). The economics of science. Journal of Economic Literature, 34, pp. 1199 - 235.

Stephan, P., \& Everhart, S. (1998). The changing rewards to science: The case of biotechnology. Small Business Economics, 10, $141-151$. 
Stephan, P. and Levin, S. (1991). Ph.D. supply. Issues in Science and Technology, 7, pp. 28 - 29.

Sousa-Poza, A. and Sousa-Poza, A.A. (2000). Taking another look at the gender / job satisfaction paradox. Kyklos, 53, pp. $135-52$.

Tsang, M. and Levin, H. (1985). The economics of overeducation. Economics of Education Review, 4, pp. 93-104.

Ward, M. E. and Sloane, P. J. (2000). Non-pecuniary advantages vs. pecuniary disadvantages: job satisfaction among male and female academics in Scottish universities. Scottish Journal of Political Economy, 47, pp. $273-303$.

Zoghi, C. (2003). Why have public university professors done so badly? Economics of Education Review, 22, pp. 45 $-57$. 
TABLE 1

Job Satisfaction and Salary by Discipline and Sector

\begin{tabular}{llccc}
\hline \multicolumn{1}{c}{ Discipline } & \multicolumn{1}{c}{ Sector } & $\begin{array}{c}\text { Average Job } \\
\text { Satisfaction }\end{array}$ & \% Very Satisfied & Average Salary \\
\hline \multirow{2}{*}{ All } & Academic & 3.43 & 52.3 & $\$ 59,881$ \\
& Nonacademic & 3.37 & 49.8 & 80,070 \\
\hline \multirow{2}{*}{ Economics } & Academic & 3.48 & 52.3 & 62,909 \\
& Nonacademic & 3.44 & 52.7 & 88,299 \\
\hline Computer & Academic & 3.45 & 53.2 & 53,818 \\
& Nonacademic & 3.44 & 54.3 & 66,880 \\
\hline \multirow{2}{*}{ Math } & Academic & 3.39 & 51.0 & 57,036 \\
& Nonacademic & 3.28 & 44.3 & 77,782 \\
\hline \multirow{2}{*}{ Hard Science } & Academic & 3.39 & 50.9 & 56,565 \\
& Nonacademic & 3.33 & 49.1 & 76,758 \\
\hline \multirow{2}{*}{ Engineering } & Academic & 3.41 & 51.5 & 56,067 \\
& Nonacademic & 3.35 & 49.2 & 72,572 \\
\hline \multirow{2}{*}{ Management } & Academic & 3.43 & 52.6 & 68,200 \\
& Nonacademic & 3.31 & 42.7 & 80,444 \\
\hline \multirow{2}{*}{ Health } & Academic & 3.56 & 60.9 & 90,202 \\
& Nonacademic & 3.47 & 56.8 & 104,885 \\
\hline Other Disciplines & Academic & 3.44 & 52.3 & 80,098 \\
& Nonacademic & 3.46 & 56.5 & 101,106 \\
\hline & Academic & 3.23 & 43.8 & 39,462 \\
& Nonacademic & 3.28 & 47.6 & 65,627 \\
\hline
\end{tabular}


TABLE 2

Variable Definitions and Means

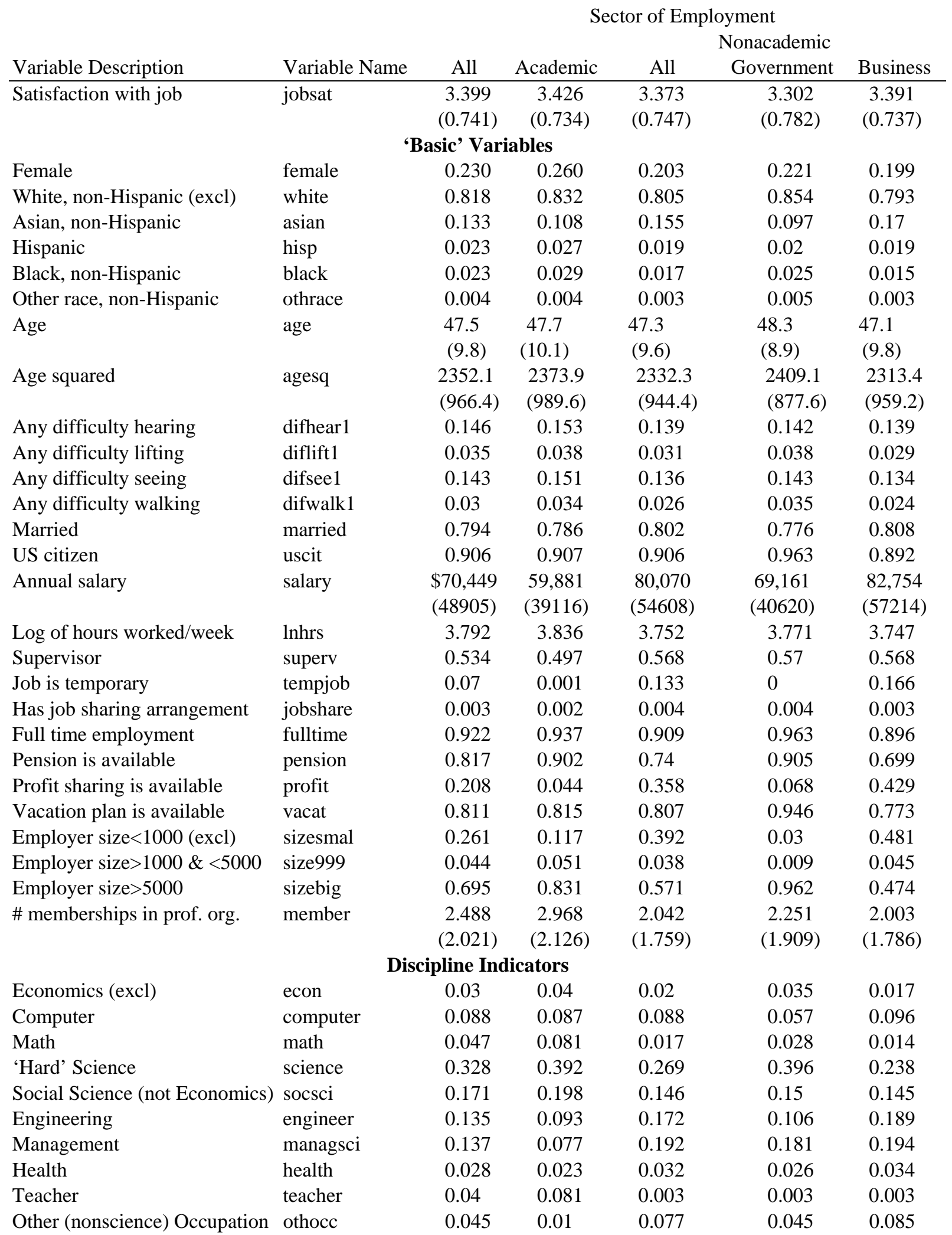


TABLE 2

continued

\begin{tabular}{|c|c|c|c|c|c|c|}
\hline Variable Description & Variable Name & Overall & Academic & All & $\begin{array}{l}\text { Nonacademic } \\
\text { Government }\end{array}$ & Business \\
\hline \multicolumn{7}{|c|}{ SDR Variables } \\
\hline \multicolumn{7}{|l|}{ Sector of employment } \\
\hline Academic & aca & 0.477 & 1 & 0 & 0 & 0 \\
\hline Nonacademic (excl) & nonaca & 0.523 & 0 & 1 & 1 & 1 \\
\hline \multicolumn{7}{|l|}{ Tenure Status } \\
\hline Worker is tenured (excl) & tenured & 0.242 & 0.507 & 0 & 0 & 0 \\
\hline Tenure track & tentrack & 0.074 & 0.154 & 0 & 0 & 0 \\
\hline No tenure in job & notenure & 0.097 & 0.204 & 0 & 0 & 0 \\
\hline Not tenure track & nottentk & 0.052 & 0.11 & 0 & 0 & 0 \\
\hline Tenure not applicable & tenurena & 0.535 & 0.025 & 1 & 1 & 1 \\
\hline \multicolumn{7}{|l|}{ Main activity at work } \\
\hline Research (excl) & research & 0.407 & 0.371 & 0.439 & 0.498 & 0.424 \\
\hline Teaching & teaching & 0.218 & 0.45 & 0.007 & 0.007 & 0.007 \\
\hline Management & manage & 0.161 & 0.092 & 0.225 & 0.226 & 0.224 \\
\hline Computer work & comput & 0.048 & 0.013 & 0.08 & 0.04 & 0.089 \\
\hline Other & othact & 0.166 & 0.073 & 0.25 & 0.229 & 0.255 \\
\hline \multicolumn{7}{|l|}{ Relation of job and degree } \\
\hline Closely relates to degree & clrelate & 0.693 & 0.835 & 0.564 & 0.643 & 0.544 \\
\hline Relates to degree & relate & 0.234 & 0.141 & 0.319 & 0.291 & 0.325 \\
\hline No relation to degree (excl) & norelate & 0.073 & 0.024 & 0.118 & 0.065 & 0.130 \\
\hline Currently on postdoc & postdoc & 0.050 & 0.079 & 0.023 & 0.058 & 0.014 \\
\hline Number of observations & & 31,845 & 15,811 & 16,034 & 3,342 & 12,692 \\
\hline
\end{tabular}

All means are weighted using sample weights. Numbers in parentheses are standard deviations for continuous variables. '(excl)' indicates that this variable was a reference variable in the ordered probit regressions. 
TABLE 3

Ordered Probit Regression Results

\begin{tabular}{|c|c|c|c|c|}
\hline & $\begin{array}{l}\text { Overall } \\
\text { (1) }\end{array}$ & $\begin{array}{l}\text { Academic } \\
\text { (2) }\end{array}$ & $\begin{array}{l}\text { Government } \\
\text { (3) }\end{array}$ & $\begin{array}{l}\text { Business } \\
\text { (4) }\end{array}$ \\
\hline \multicolumn{5}{|c|}{ 'Basic Variables' } \\
\hline \multirow[t]{2}{*}{ Female } & -0.021 & $-0.085 * * *$ & -0.061 & $0.084 * *$ \\
\hline & -1.095 & -3.202 & -1.053 & 2.534 \\
\hline \multirow[t]{2}{*}{ Asian } & $-0.114^{* * *}$ & $-0.076 * *$ & -0.052 & $-0.145^{* * *}$ \\
\hline & -4.560 & -1.968 & -0.682 & -3.983 \\
\hline \multirow[t]{2}{*}{ Hispanic } & 0.012 & 0.088 & -0.053 & -0.093 \\
\hline & 0.261 & 1.470 & -0.382 & -1.182 \\
\hline \multirow[t]{2}{*}{ Black } & $-0.157 * * *$ & $-0.166 * * *$ & 0.030 & $-0.202 * *$ \\
\hline & -3.540 & -2.880 & 0.248 & -2.378 \\
\hline \multirow[t]{2}{*}{ Other race } & $-0.189 *$ & -0.154 & -0.231 & -0.188 \\
\hline & -1.674 & -1.114 & -1.002 & -0.755 \\
\hline \multirow[t]{2}{*}{ Age } & $-0.085^{* * *}$ & $-0.088 * * *$ & $-0.073 * * *$ & $-0.086 * * *$ \\
\hline & -11.469 & -8.004 & -2.896 & -7.512 \\
\hline \multirow[t]{2}{*}{ Age squared } & $9.6 \mathrm{E}-04 * * *$ & $9.9 \mathrm{E}-04 * * *$ & $7.7 \mathrm{E}-04^{* * *}$ & $9.8 \mathrm{E}-04^{* * *}$ \\
\hline & 12.673 & 8.975 & 3.051 & 8.222 \\
\hline \multirow[t]{2}{*}{ Difficulty hearing } & $-0.162 * * *$ & $-0.194 * * *$ & -0.103 & $-0.138 * * *$ \\
\hline & -6.536 & -5.740 & -1.211 & -3.478 \\
\hline \multirow[t]{2}{*}{ Difficulty lifting } & $-0.133^{* * *}$ & $-0.130 * *$ & -0.176 & -0.123 \\
\hline & -2.817 & -2.089 & -1.230 & -1.477 \\
\hline \multirow[t]{2}{*}{ Difficulty seeing } & $-0.151^{* * *}$ & $-0.143^{* * *}$ & $-0.249 * * *$ & $-0.141 * * *$ \\
\hline & -6.130 & -4.124 & -3.195 & -3.576 \\
\hline \multirow[t]{2}{*}{ Difficulty walking } & $-0.089 *$ & $-0.125^{*}$ & -0.156 & 0.031 \\
\hline & -1.680 & -1.763 & -1.047 & 0.344 \\
\hline \multirow[t]{2}{*}{ Married } & $0.134 * * *$ & $0.136^{* * *}$ & $0.098^{*}$ & $0.138 * * *$ \\
\hline & 6.584 & 4.764 & 1.649 & 4.153 \\
\hline \multirow[t]{2}{*}{ US citizen } & $0.077^{* *}$ & $0.104^{* *}$ & 0.140 & 0.037 \\
\hline & 2.566 & 2.403 & 1.037 & 0.834 \\
\hline \multirow[t]{2}{*}{ Ln(salary) } & $0.208^{* * *}$ & $0.233^{* * *}$ & 0.066 & $0.212^{* * *}$ \\
\hline & 11.044 & 7.942 & 0.940 & 8.139 \\
\hline \multirow[t]{2}{*}{ Ln(hours) } & 0.026 & -0.009 & $0.333^{* *}$ & 0.030 \\
\hline & 0.697 & -0.176 & 2.160 & 0.532 \\
\hline \multirow[t]{2}{*}{ Supervisor } & $0.115 * * *$ & $0.083^{* * *}$ & $0.278 * * *$ & $0.105^{* * *}$ \\
\hline & 6.220 & 3.111 & 5.063 & 3.659 \\
\hline \multirow[t]{2}{*}{ Temporary job } & $0.319 * * *$ & 0.400 & & $0.219 * * *$ \\
\hline & 7.216 & 1.221 & & 4.311 \\
\hline \multirow[t]{2}{*}{ Jobshare } & -0.156 & 0.031 & $-0.594^{*}$ & -0.223 \\
\hline & -1.285 & 0.123 & -1.890 & -1.514 \\
\hline \multirow[t]{2}{*}{ Full time } & $-0.142 * * *$ & $-0.194 * * *$ & $-0.540 * *$ & -0.010 \\
\hline & -2.978 & -2.889 & -2.481 & -0.144 \\
\hline \multirow[t]{2}{*}{ Pension available } & $0.054^{*}$ & 0.038 & 0.072 & $0.148^{* * *}$ \\
\hline & 1.909 & 0.876 & 0.590 & 3.570 \\
\hline \multirow[t]{2}{*}{ Profit sharing } & $0.148^{* * *}$ & $0.105^{*}$ & 0.120 & $0.183^{* * *}$ \\
\hline & 6.134 & 1.789 & 1.127 & 6.463 \\
\hline Vacation available & -0.010 & $0.084^{* *}$ & -0.144 & $-0.226 * * *$ \\
\hline & -0.373 & 2.554 & -0.989 & -4.158 \\
\hline Empl size $>1000 \&<5000$ & $-0.136 * * *$ & 0.019 & -0.239 & $-0.269 * * *$ \\
\hline & -3.298 & 0.313 & -0.898 & -4.638 \\
\hline Empl size $>=5000$ & $-0.150 * * *$ & $-0.092 * *$ & -0.102 & $-0.187 * * *$ \\
\hline & -6.349 & -2.406 & -0.729 & -5.909 \\
\hline
\end{tabular}




\begin{tabular}{|c|c|c|c|c|}
\hline \multirow{3}{*}{ Computer science } & \multicolumn{2}{|c|}{ Discipline Indicators } & \multirow[b]{2}{*}{0.063} & \multirow[b]{2}{*}{-0.021} \\
\hline & 0.068 & $0.376^{* *}$ & & \\
\hline & 0.956 & 2.314 & 0.264 & -0.177 \\
\hline \multirow[t]{2}{*}{ Math } & $-0.148 * *$ & $-0.426 * * *$ & -0.126 & -0.074 \\
\hline & -2.459 & -2.777 & -0.556 & -0.613 \\
\hline \multirow[t]{2}{*}{ 'Hard' science } & -0.040 & 0.008 & -0.057 & -0.130 \\
\hline & -0.735 & 0.120 & -0.367 & -1.161 \\
\hline \multirow{2}{*}{ Social science } & 0.015 & 0.052 & -0.112 & -0.045 \\
\hline & 0.252 & 0.726 & -0.664 & -0.381 \\
\hline \multirow[t]{2}{*}{ Engineering } & $-0.104 *$ & -0.074 & -0.136 & -0.154 \\
\hline & -1.796 & -0.961 & -0.803 & -1.355 \\
\hline \multirow[t]{2}{*}{ Managerial science } & $0.161^{* * *}$ & $0.182 * *$ & -0.028 & 0.136 \\
\hline & 2.627 & 2.017 & -0.168 & 1.183 \\
\hline \multirow[t]{2}{*}{ Health } & $0.169 * *$ & 0.151 & 0.271 & 0.072 \\
\hline & 2.257 & 1.387 & 1.330 & 0.539 \\
\hline \multirow[t]{2}{*}{ Teacher } & -0.022 & 0.012 & -0.057 & 0.072 \\
\hline & -0.333 & 0.151 & -0.119 & 0.268 \\
\hline \multirow[t]{3}{*}{ Other discipline } & 0.108 & 0.096 & 0.083 & 0.043 \\
\hline & 1.556 & 0.728 & 0.412 & 0.357 \\
\hline & SDR & riables & & \\
\hline \multirow[t]{2}{*}{ Academic sector } & 0.079 & & & \\
\hline & 0.986 & & & \\
\hline \multirow[t]{2}{*}{ Government sector } & 0.013 & & & \\
\hline & 0.397 & & & \\
\hline \multirow[t]{2}{*}{ Tenure track } & $-0.167 * * *$ & $-0.151 * * *$ & & \\
\hline & -4.639 & -3.938 & & \\
\hline \multirow[t]{2}{*}{ No tenure in job } & $-0.151^{* * *}$ & $-0.137 * * *$ & & \\
\hline & -4.485 & -3.783 & & \\
\hline \multirow[t]{2}{*}{ Job not tenure track } & $-0.257 * * *$ & $-0.241^{* * * *}$ & & \\
\hline & -6.656 & -5.947 & & \\
\hline \multirow[t]{2}{*}{ Tenure not applicable } & $-0.204^{* *}$ & $-0.208 * *$ & & \\
\hline & -2.556 & -2.541 & & \\
\hline \multirow[t]{2}{*}{ Teaching is primary activity } & -0.044 & -0.043 & 0.463 & $0.384 * *$ \\
\hline & -1.575 & -1.364 & 1.546 & 2.383 \\
\hline \multirow[t]{2}{*}{ Management is primary act. } & $-0.087 * * *$ & -0.065 & $-0.183^{* *}$ & $-0.071^{*}$ \\
\hline & -2.912 & -1.148 & -2.392 & -1.751 \\
\hline Computers are primary act. & $-0.129 * * *$ & $-0.241^{* *}$ & -0.157 & $-0.088^{*}$ \\
\hline & -2.937 & -2.164 & -1.281 & -1.653 \\
\hline Other primary activity & $-0.096 * * *$ & -0.026 & $-0.180 * *$ & $-0.123 * * *$ \\
\hline & -3.321 & -0.500 & -2.507 & -2.838 \\
\hline Job closely relates to degree & $0.434^{* * *}$ & $0.467 * * *$ & $0.408^{* * *}$ & $0.448 * * *$ \\
\hline & 11.705 & 5.808 & 3.654 & 9.672 \\
\hline Job relates to degree & $0.115^{* * *}$ & $0.176^{* *}$ & 0.174 & $0.094 * *$ \\
\hline & 3.123 & 2.136 & 1.553 & 2.109 \\
\hline Currently on postdoc & -0.051 & $-0.107^{*}$ & -0.062 & 0.128 \\
\hline & -1.209 & -1.921 & -0.473 & 1.235 \\
\hline MU(1) & $-1.251^{* * *}$ & $-1.086 * * *$ & $-1.832 * *$ & $-1.104^{* * *}$ \\
\hline & -4.750 & -2.746 & -1.977 & -3.178 \\
\hline MU(2) & $-0.534^{* *}$ & -0.389 & -1.038 & -0.381 \\
\hline & -2.028 & -0.985 & -1.125 & -1.093 \\
\hline MU(3) & $0.727 * * *$ & $0.854^{* *}$ & 0.193 & $0.923^{* * *}$ \\
\hline & 2.759 & 2.163 & 0.209 & 2.651 \\
\hline Log Likelihood & -30491.33 & -14848.07 & -3447.06 & -12068.50 \\
\hline
\end{tabular}

Notes: Significance: *,**, $* * *$ indicate $10 \%, 5 \%$, and $1 \%$, respectively. t-statistics under coefficient estimates. There were no observations for 'tempjob' in the government sector. Excluded variables: tenured, research activity, white, and economics discipline. Regressions weighted by sample weights. 
TABLE 4

Female Coefficient from Job Satisfaction Ordered Probits by Discipline

\begin{tabular}{llcc} 
& & Sample & Business \\
\hline Discipline & Overall & Academic & $0.084^{* * *}$ \\
Economics & -0.021 & $-0.085^{* * *}$ & -0.190 \\
Social Science & $-0.212^{*}$ & -0.207 & 0.105 \\
Computers & -0.020 & $-0.114^{* *}$ & 0.085 \\
Math & 0.040 & 0.038 & 0.100 \\
Hard Sciences & -0.005 & 0.014 & -0.032 \\
Engineers & $-0.083^{* * *}$ & $-0.114^{* * *}$ & $-0.155^{*}$ \\
Managerial Science & $-0.159^{* *}$ & $-0.201^{*}$ & 0.097 \\
Health & -0.038 & $-0.205^{*}$ & 0.120 \\
Other disciplines & -0.004 & -0.157 & $0.261^{* *}$ \\
\hline
\end{tabular}

Notes:

Other covariates controlled for are the same as in Table 3, with subdiscipline indicators where applicable. Significance: *, **, *** indicate $10 \%, 5 \%$, and $1 \%$, respectively. 
TABLE 5

Job Satisfaction Regressions by Sector and Gender

Academic

Business

\begin{tabular}{|c|c|c|c|c|}
\hline & Female & Male & Female & Male \\
\hline \multicolumn{5}{|c|}{ 'Basic' Variables } \\
\hline \multirow[t]{2}{*}{ Asian } & 0.056 & $-0.119 * *$ & $-0.194 * *$ & $-0.131 * * *$ \\
\hline & 0.890 & -2.509 & -2.332 & -3.234 \\
\hline \multirow[t]{2}{*}{ Hispanic } & -0.084 & $0.189 * *$ & -0.222 & -0.081 \\
\hline & -0.961 & 2.462 & -1.457 & -0.871 \\
\hline \multirow[t]{2}{*}{ Black } & -0.116 & $-0.192 * *$ & $-0.348 * *$ & -0.162 \\
\hline & -1.437 & -2.373 & -2.325 & -1.535 \\
\hline \multirow[t]{2}{*}{ Other race } & -0.225 & -0.156 & -0.074 & -0.284 \\
\hline & -0.814 & -0.945 & -0.219 & -0.947 \\
\hline \multirow[t]{2}{*}{ Age } & $-0.033^{* *}$ & $-0.112 * * *$ & $-0.072 * * *$ & $-0.091 * * *$ \\
\hline & -1.985 & -8.135 & -3.370 & -6.827 \\
\hline \multirow[t]{2}{*}{ Age squared } & $4.3 \mathrm{E}-4^{* *}$ & $1.2 \mathrm{E}-3^{* * *}$ & $8.2 \mathrm{E}-4^{* * *}$ & $1.0 \mathrm{E}-3 * * *$ \\
\hline & 2.465 & 8.994 & 3.688 & 7.452 \\
\hline \multirow[t]{2}{*}{ Difficulty hearing } & -0.034 & $-0.238 * * *$ & -0.023 & $-0.152 * * *$ \\
\hline & -0.594 & -6.142 & -0.270 & -3.482 \\
\hline \multirow[t]{2}{*}{ Difficulty lifting } & -0.107 & $-0.153 * *$ & $-0.206 * *$ & -0.055 \\
\hline & -1.453 & -1.761 & -2.097 & -0.477 \\
\hline \multirow[t]{2}{*}{ Difficulty seeing } & $-0.180^{* * *}$ & $-0.131^{* * *}$ & $-0.226 * * *$ & $-0.118^{* * *}$ \\
\hline & -3.574 & -3.148 & -3.074 & -2.702 \\
\hline \multirow[t]{2}{*}{ Difficulty walking } & -0.138 & -0.117 & $3.9 \mathrm{E}-4$ & 7.4E-5 \\
\hline & -1.417 & -1.323 & 0.003 & 0.001 \\
\hline \multirow[t]{2}{*}{ Married } & $0.104 * * *$ & $0.147 * * *$ & $0.146 * * *$ & $0.136^{* * *}$ \\
\hline & 3.046 & 3.807 & 3.001 & 3.319 \\
\hline \multirow[t]{2}{*}{ US citizen } & 0.109 & $0.099 *$ & 0.090 & 0.027 \\
\hline & 1.634 & 1.901 & 0.946 & 0.540 \\
\hline \multirow[t]{2}{*}{ Ln(salary) } & $0.154 * * *$ & $0.269 * * *$ & $0.203^{* * *}$ & $0.222 * * *$ \\
\hline & 3.867 & 7.167 & 5.483 & 7.216 \\
\hline \multirow[t]{2}{*}{ Ln(hours) } & -0.086 & 0.024 & -0.125 & 0.114 \\
\hline & -1.311 & 0.362 & -1.624 & 1.607 \\
\hline \multirow[t]{2}{*}{ Supervisor } & $0.125^{* * *}$ & $0.070 * *$ & $0.119 * *$ & $0.104^{* * *}$ \\
\hline & 3.428 & 2.111 & 2.349 & 3.154 \\
\hline \multirow[t]{2}{*}{ Temporary job } & $0.706 * *$ & 0.016 & $0.435^{* * *}$ & $0.127 * *$ \\
\hline & 1.975 & 0.041 & 5.941 & 2.075 \\
\hline \multirow[t]{2}{*}{ Jobshare } & 0.137 & -0.084 & -0.182 & -0.233 \\
\hline & 0.461 & -0.231 & -0.595 & -1.353 \\
\hline \multirow[t]{2}{*}{ Full time } & -0.094 & $-0.223^{* *}$ & $0.224^{* * *}$ & -0.150 \\
\hline & -1.142 & -2.383 & 2.647 & -1.548 \\
\hline \multirow[t]{2}{*}{ Pension available } & 0.040 & 0.052 & 0.133* & $0.159 * * *$ \\
\hline & 0.690 & 0.932 & 1.930 & 3.273 \\
\hline \multirow[t]{2}{*}{ Profit sharing } & $0.128 *$ & 0.096 & 0.095* & $0.196 * * *$ \\
\hline & 1.763 & 1.243 & 1.708 & 6.174 \\
\hline \multirow[t]{2}{*}{ Vacation available } & 0.067 & $0.088 * *$ & $-0.159 *$ & $-0.254 * * *$ \\
\hline & 1.455 & 2.226 & -1.879 & -3.954 \\
\hline \multirow[t]{2}{*}{ Empl size $>1000 \&<5000$} & $0.137 *$ & -0.033 & $-0.461 * * *$ & $-0.215^{* * *}$ \\
\hline & 1.661 & -0.420 & -4.440 & -3.170 \\
\hline Empl size $>=5000$ & $-0.104 * *$ & $-0.085^{*}$ & $-0.189 * * *$ & $-0.187 * * *$ \\
\hline & -2.170 & -1.720 & -3.248 & -5.171 \\
\hline
\end{tabular}




\begin{tabular}{|c|c|c|c|c|}
\hline \multirow{2}{*}{ Computer science } & \multicolumn{2}{|c|}{ Discipline Indicators } & \multirow[b]{2}{*}{$0.375^{*}$} & \multirow[b]{2}{*}{-0.120} \\
\hline & $0.912 * * *$ & 0.239 & & \\
\hline & 2.914 & 1.328 & 1.942 & -0.808 \\
\hline \multirow[t]{2}{*}{ Math } & $-0.876 * * *$ & $-0.312^{*}$ & -0.313 & -0.030 \\
\hline & -2.921 & -1.827 & -1.532 & -0.227 \\
\hline \multirow[t]{2}{*}{ 'Hard' science } & 0.010 & 0.005 & 0.008 & -0.187 \\
\hline & 0.087 & 0.070 & 0.050 & -1.331 \\
\hline \multirow[t]{2}{*}{ Social science } & 0.096 & 0.039 & 0.134 & -0.133 \\
\hline & 0.833 & 0.476 & 0.818 & -0.881 \\
\hline \multirow[t]{2}{*}{ Engineering } & -0.136 & -0.080 & -0.120 & -0.218 \\
\hline & -0.903 & -0.957 & -0.686 & -1.544 \\
\hline \multirow[t]{2}{*}{ Managerial science } & $0.242 *$ & 0.151 & $0.315^{*}$ & 0.066 \\
\hline & 1.734 & 1.454 & 1.868 & 0.462 \\
\hline \multirow[t]{2}{*}{ Health } & $0.256 *$ & 0.099 & 0.202 & 0.045 \\
\hline & 1.652 & 0.712 & 1.095 & 0.270 \\
\hline \multirow[t]{2}{*}{ Teacher } & 0.009 & 0.028 & $1.423 * * *$ & -0.464 \\
\hline & 0.077 & 0.299 & 3.104 & -1.487 \\
\hline \multirow[t]{2}{*}{ Other discipline } & 0.221 & 0.034 & 0.309* & -0.047 \\
\hline & 1.241 & 0.196 & 1.744 & -0.316 \\
\hline \multicolumn{5}{|c|}{ 'SDR' Variables } \\
\hline \multirow[t]{2}{*}{ Tenure track } & 0.004 & $-0.229 * * *$ & & \\
\hline & 0.080 & -4.593 & & \\
\hline \multirow[t]{2}{*}{ No tenure in job } & -0.086 & $-0.145^{* * *}$ & & \\
\hline & -1.633 & -3.275 & & \\
\hline \multirow[t]{2}{*}{ Job not tenure track } & $-0.168 * * *$ & $-0.268 * * *$ & & \\
\hline & -3.055 & -5.248 & & \\
\hline \multirow[t]{2}{*}{ Tenure not applicable } & $-0.154^{*}$ & $-0.221 *$ & & \\
\hline & -1.798 & -1.829 & & \\
\hline \multirow[t]{2}{*}{ Teaching is primary activity } & -0.036 & -0.038 & -0.070 & $0.558 * * *$ \\
\hline & -0.812 & -0.993 & -0.281 & 2.832 \\
\hline \multirow[t]{2}{*}{ Management is primary act. } & $-0.179 * *$ & -0.018 & 0.006 & $-0.087^{*}$ \\
\hline & -2.357 & -0.269 & 0.082 & -1.915 \\
\hline \multirow[t]{2}{*}{ Computers are primary act. } & -0.225 & $-0.230 *$ & $-0.225^{*}$ & -0.065 \\
\hline & -1.246 & -1.740 & -1.791 & -1.135 \\
\hline \multirow[t]{2}{*}{ Other primary activity } & -0.056 & -0.020 & -0.084 & $-0.125^{* *}$ \\
\hline & -0.866 & -0.277 & -1.206 & -2.449 \\
\hline \multirow[t]{2}{*}{ Job closely relates to degree } & $0.426 * * *$ & $0.476^{* * *}$ & $0.413^{* * *}$ & $0.453 * * *$ \\
\hline & 4.194 & 4.686 & 4.851 & 8.629 \\
\hline Job relates to degree & 0.112 & 0.199* & $0.182 * *$ & 0.074 \\
\hline & 1.075 & 1.907 & 2.221 & 1.482 \\
\hline Currently on postdoc & -0.061 & $-0.130 *$ & $0.675^{* * *}$ & -0.100 \\
\hline & -0.879 & -1.758 & 4.320 & -0.768 \\
\hline MU(1) & -0.685 & -1.247 & -0.954 & -1.055 \\
\hline & -1.212 & -2.499 & -1.569 & -2.581 \\
\hline $\mathrm{MU}(2)$ & -0.009 & -0.534 & -0.306 & -0.307 \\
\hline & -0.016 & -1.073 & -0.505 & -0.751 \\
\hline MU(3) & 1.217 & 0.721 & 0.964 & 1.012 \\
\hline & 2.154 & 1.448 & 1.588 & 2.475 \\
\hline Log likelihood & -5305.29 & -9633.77 & -2755.99 & -9258.58 \\
\hline
\end{tabular}

Notes:

Significance: *,**, *** indicate $10 \%, 5 \%$, and 1\%, respectively. t-statistics under coefficient estimates. Excluded variables: tenured, research activity, white, and economics discipline. Regressions weighted by sample weights. 
TABLE 6

Evolution of the Academic Job Satisfaction Coefficient

\begin{tabular}{lccc} 
Sample & Coefficient & t-stat & Variable Specification \\
\hline Overall & 0.257 & 10.484 & Basic \\
& 0.231 & 8.812 & Basic+Activity \\
& 0.171 & 6.487 & Basic+Activity +Relate \\
& 0.079 & 0.986 & Basic+Activity+Relate+Tenure Status \\
Tenured and & 0.288 & 8.081 & Basic+Activity +Relate \\
Nonacademic & & & \\
Not Tenured and & 0.057 & 0.688 & Basic+Activity+Relate+Tenure Status \\
Nonacademic & & & \\
\hline
\end{tabular}

Notes:

'Basic' specification includes all variables identified in Table 2 as 'Basic Variables'. 'Activity' includes the major job activity of the scientists. 'Relate' includes the variables that capture how closely related the scientist's training is to his or her current job. 'Tenure Status' includes the five variables identifying tenure status. Since there are no tenured academics in the third sample above, the excluded tenure status variable is 'tentrack'. Full results are available from the authors. 
TABLE 7

Comparison Income by Discipline

\begin{tabular}{|c|c|c|c|}
\hline Discipline & Sector & Salary >acahat & Salary > nacahat \\
\hline \multirow[t]{3}{*}{ All } & Overall & $0.075^{* * *}$ & $0.102^{* * *}$ \\
\hline & Academic & $0.071 * *$ & $0.076 * *$ \\
\hline & Business & $0.079 *$ & $0.118 * * *$ \\
\hline \multirow[t]{3}{*}{ Economics } & Overall & $0.260 * *$ & -0.113 \\
\hline & Academic & $0.383^{* *}$ & -0.020 \\
\hline & Business & -0.068 & -0.023 \\
\hline \multirow[t]{3}{*}{ Social Science } & Overall & $0.203^{* * *}$ & $0.121^{* *}$ \\
\hline & Academic & $0.263 * *$ & 0.024 \\
\hline & Business & 0.123 & $0.309 * * *$ \\
\hline \multirow[t]{3}{*}{ Computer } & Overall & $0.147 * *$ & $0.219 * * *$ \\
\hline & Academic & $0.156^{*}$ & 0.154 \\
\hline & Business & 0.175 & $0.268 * * *$ \\
\hline \multirow[t]{3}{*}{ Math } & Overall & $0.182^{* *}$ & 0.065 \\
\hline & Academic & 0.147 & 0.046 \\
\hline & Business & 0.271 & 0.113 \\
\hline \multirow[t]{3}{*}{ Hard Science } & Overall & $0.088 * *$ & $0.131^{* * *}$ \\
\hline & Academic & $0.127 * * *$ & 0.082 \\
\hline & Business & 0.094 & $0.206^{* * *}$ \\
\hline \multirow[t]{3}{*}{ Engineering } & Overall & $0.159 * *$ & $0.086 * * *$ \\
\hline & Academic & $0.169 *$ & 0.139 \\
\hline & Business & $0.178^{* *}$ & $0.203 * * *$ \\
\hline \multirow[t]{3}{*}{ Management } & Overall & 0.028 & $0.141^{* *}$ \\
\hline & Academic & -0.008 & $0.270^{* *}$ \\
\hline & Business & 0.100 & $0.120 *$ \\
\hline \multirow[t]{3}{*}{ Health } & Overall & 0.146 & 0.026 \\
\hline & Academic & 0.092 & -0.142 \\
\hline & Business & 0.210 & 0.041 \\
\hline \multirow[t]{3}{*}{ Other } & Overall & $0.404 * * *$ & 0.009 \\
\hline & Academic & 0.043 & -0.549 \\
\hline & Business & $0.507 * * *$ & -0.001 \\
\hline
\end{tabular}

Notes:

Significance: *,**,*** indicate $10 \%, 5 \%$, and $1 \%$, respectively. 'Acahat' is the predicted academic earnings for each worker. 'Nacahat' is the predicted nonacademic earnings for each worker. Full results are available from the authors. 
Data Appendix for 'Job Satisfaction of the Highly Educated: The Role of Gender, Academic Tenure, and Comparison Income', by Keith A. Bender and John S. Heywood

APPENDIX TABLE 1.

Log Salary Regressions by Sector of Employment

\begin{tabular}{|c|c|c|c|c|c|}
\hline Variable & Academic & Nonacademic & Variable & Academic & Nonacademic \\
\hline \multirow[t]{2}{*}{ \# Professional memberships } & $0.030 * * *$ & $0.024^{* * *}$ & Supervisor & $0.110^{* * *}$ & $0.108^{* * *}$ \\
\hline & 13.521 & 7.521 & & 12.898 & 9.116 \\
\hline \multirow[t]{2}{*}{ Region midatlantic } & 0.001 & $0.058 * *$ & Pension & $0.209 * * *$ & $0.101^{* * *}$ \\
\hline & 0.090 & 2.210 & & 9.401 & 5.478 \\
\hline \multirow[t]{2}{*}{ Region east north central } & $-0.054 * * *$ & $-0.058 * *$ & Health insurance & $0.477 * * *$ & $0.066 * *$ \\
\hline & -3.367 & -2.183 & & 11.506 & 2.461 \\
\hline \multirow[t]{2}{*}{ Region west north central } & $-0.111 * * *$ & $-0.141 * * *$ & Profit sharing & $0.031 *$ & $0.139 * * *$ \\
\hline & -6.327 & -4.126 & & 1.716 & 13.450 \\
\hline \multirow[t]{2}{*}{ Region south atlantic } & $-0.046 * * *$ & 0.012 & Computer science & 0.094 & $-0.084^{* *}$ \\
\hline & -2.810 & 0.490 & & 1.632 & -2.014 \\
\hline \multirow[t]{2}{*}{ Region east south central } & $-0.132 * * *$ & $-0.079 * *$ & Mathematics & $-0.139 * *$ & -0.036 \\
\hline & -6.665 & -2.169 & & -2.506 & -0.862 \\
\hline \multirow[t]{2}{*}{ Region west south central } & $-0.126^{* * *}$ & -0.045 & 'Hard’ science & $-0.137 * * *$ & $-0.191 * * *$ \\
\hline & -6.762 & -1.527 & & -6.605 & -4.980 \\
\hline \multirow[t]{2}{*}{ Region mountain } & $-0.071 * * *$ & $-0.085 * * *$ & Social science & $-0.184 * * *$ & $-0.180 * * *$ \\
\hline & -3.512 & -2.894 & & -8.337 & -4.312 \\
\hline \multirow[t]{2}{*}{ Region Pacific } & -0.014 & 0.038 & Engineering & $0.050 * *$ & $-0.084 * *$ \\
\hline & -0.803 & 1.517 & & 2.233 & -2.156 \\
\hline \multirow[t]{2}{*}{ Female } & $-0.125 * * *$ & $-0.137 * * *$ & Managerial sci & $0.087 * * *$ & 0.033 \\
\hline & -13.831 & -9.332 & & 3.172 & 0.802 \\
\hline \multirow[t]{2}{*}{ Asian } & $-0.048^{* * *}$ & -0.018 & Health science & 0.060 & $1.1 \mathrm{E}-3$ \\
\hline & -3.467 & -1.499 & & 1.426 & 0.022 \\
\hline \multirow[t]{2}{*}{ Hispanic } & $-0.046 * * *$ & 0.023 & Teacher & $-0.109 * * *$ & -0.174 \\
\hline & -2.869 & 0.640 & & -4.121 & -0.525 \\
\hline \multirow[t]{2}{*}{ Black } & -0.024 & -0.018 & Other discipline & $-0.379 * * *$ & $-0.363^{* * *}$ \\
\hline & -1.383 & -0.548 & & -6.100 & -7.843 \\
\hline \multirow[t]{2}{*}{ Other race } & $-0.156^{* * *}$ & -0.010 & Activity:Teaching & $-0.168 * * *$ & -0.104 \\
\hline & -4.326 & -0.148 & & -17.584 & -1.180 \\
\hline \multirow[t]{2}{*}{ Age } & $0.053^{* * *}$ & $0.079 * * *$ & Activity: Manage & $-0.030 *$ & -0.021 \\
\hline & 12.838 & 14.513 & & -1.710 & -1.303 \\
\hline \multirow[t]{2}{*}{ Age squared } & $-4.1 \mathrm{E}-4^{* * *}$ & $-7.6 \mathrm{E}-4 * * *$ & Activity: computer & $-0.134 * * *$ & 0.016 \\
\hline & -9.600 & -13.040 & & -3.290 & 0.841 \\
\hline \multirow[t]{2}{*}{ Married } & $0.031 * * *$ & $0.103^{* * *}$ & Activity: Other & -0.025 & -0.005 \\
\hline & 3.186 & 6.797 & & -1.189 & -0.247 \\
\hline \multirow[t]{2}{*}{ Empl size $>1000 \&<5000$} & $0.043^{*}$ & -0.012 & Currently postdoc & $-0.308 * * *$ & $-0.349 * * *$ \\
\hline & 1.925 & -0.477 & & -16.890 & -12.888 \\
\hline \multirow[t]{2}{*}{ Empl size $>=5000$} & $0.053^{* * *}$ & -0.013 & Constant & $8.241^{* * *}$ & $8.402 * * *$ \\
\hline & 3.763 & -0.957 & & 82.268 & 67.207 \\
\hline \multirow[t]{2}{*}{ Full time } & $0.564^{* * *}$ & $0.633^{* * *}$ & R-squared & 0.495 & 0.316 \\
\hline & 17.330 & 17.228 & & & \\
\hline
\end{tabular}

Notes:

All variables are defined in Table 2 of the paper except 'regma' - 'regpac' which identify Census region of residence (New England region is excluded). '\# of Professional memberships' and region are the identifiers of the salary equations and therefore are not included in the job satisfaction regression. When included they are insignificant. t-statistics are under coefficient estimates. *, **, *** indicate $10 \%, 5 \%$, and $1 \%$ significance, respectively. 
APPENDIX TABLE 2.

Occupations Identified in the 1997 SDR

\section{Computer Scientists}

Computer Systems Analysts

Computer Scientists, Except Systems Analysts

Information Systems Scientists etc

OTHER Computer and Information Science

Computer Engineers-Software

Postsecondary Teachers-Computer Science

\section{Mathematicians}

Mathematicians

Operations Research Analysts, etc

Statisticians

OTHER Mathematical Scientists

Postsecondary Teachers-Math Science

\section{'Hard' Scientists}

Agricultural and Food Scientists

Postsecondary Teachers-Agriculture

Biochemists and Biophysicists

Biological scientists

Postsecondary Teachers-Biological Science

Medical Scientists, Except Practitioners

Postsecondary Teachers-Medical Science

OTHER Biological and Life Scientists

Forestry and Conservation Scientist

OTHER Postsecondary Teachers-Biology

Chemists, except Biochemists

Postsecondary Teachers-Chemistry

Atmospheric and Space Scientists

Geologists

Oceanographers

Postsecondary Teachers-Earth, Environmental Sciences

Astronomer

Physicists

Postsecondary Teachers-Physics

OTHER Physical and Related Scientists

\section{Economists}

Economists

Postsecondary Teachers-Economics

\section{Social Scientists (not Economists)}

Political Scientists

Postsecondary Teachers-Political Science

Psychologists

Postsecondary Teachers-Psychology

Anthropologists

Sociologists

Postsecondary Teachers-Sociology

Historians, Science and Technology

OTHER Social Scientists

Postsecondary Teachers-OTHER Social Scientists 
Appendix Table 2 continued

\section{Engineers}

Aerospace and related Engineers

Chemical Engineers

Civil Engineers

Computer Engineers-Hardware

Electrical and Electronics Engineers

Industrial engineers

Mechanical Engineers

Agricultural Engineers

Bioengineers and Biomedical Engineers

Environmental Engineers

Marine Engineers or Naval Architects

Materials and Metallurgical Engineers

Mining and Geological Engineers

Nuclear Engineers

Petroleum Engineers

Sales Engineers

OTHER Engineers

Postsecondary Teachers - Engineering

\section{Management}

Top and Mid-Level Managers, Executives

Accountants, Auditors, and other

Personnel, Training and Labor Relations

OTHER Management Related Occupations

\section{Health}

Diagnosing and Treating Health Professionals

Registered Nurses, Pharmacists

Health Technologists and Technicians

OTHER Health Occupations

\section{Teachers}

Teachers, Pre-Kindergarten and Kindergarten

Teachers, Elementary School

Teachers, Secondary-Computer, Math

Teachers, Social Sciences

Teachers, OTHER Subjects

Teachers, Special Education

Teachers, OTHER Precollegiate Education

Postsecondary Teachers-Art, Drama

Postsecondary Teachers-Business, Economics

Postsecondary Teachers-Education

Postsecondary Teachers-English Teachers

Postsecondary Teachers-Foreign Language

Postsecondary Teachers-History Teachers

Postsecondary Teachers-Home Economics

Postsecondary Teachers-Law Teachers

Postsecondary Teachers-Physical Education

Postsecondary Teachers-Social Work

Postsecondary Teachers-Theology

Postsecondary Teachers-Trade and Industry

Postsecondary Teachers-OTHER Health

Postsecondary Teachers-OTHER, Non-science 
Appendix Table 2 continued

\section{Other nonscience Occupations}

Clergy and OTHER Religious Worker

Counselors, Educational and Vocational

Social Workers

Technologists/Technicians In Biotechnology

Computer Programmers

E\&E, Indus., Mechanical Engineers

Drafting Occupations

Surveying/Mapping Engineers Technology

OTHER Engineers Technologists/Technicians

Surveyors

Technologists/Technicians In Math

Technologists/Technicians In Physical Sciences

Sales/Mrkt. - Insurance, Securities

Sales Occupations - Commodities

Sales Occupations - Retail

OTHER Marketing and Sales Occupations

Artists, Editors, Entertainers,

Historians, Except Science and Teachers

Accounting Clerks and Bookkeepers

Secretaries, Receptionists and Typing

OTHER Administrative

Architects

Farmers, Foresters and Fishermen

Lawyers and Judges

Librarians, Archivists and Curators

Actuaries

Food Preparation and Service Workers

Protective Service Workers

OTHER Service Occupations

Construction Trades, Miners

Mechanics and Repairers

Precision Production Occupations

Operators and Related Occupations

Transportation and material-moving

OTHER Occupations 